\title{
Paulo Bruscky e a esfera pública: uma análise da agência artística de Arte Cemiterial
}

Raíza Ribeiro Cavalcanti*

http://dx.doi.org/10.22409/poiesis.1829.247268

\begin{abstract}
RESUMO: Neste artigo pretendo investigar, através do trabalho Arte Cemiterial do artista Paulo Bruscky, a relação entre arte e esfera pública. Desse modo, parto do conceito sociológico de agenciamento artístico para analisar como o trabalho atua tanto no espaço urbano onde foi realizado quanto na esfera pública de que participa (o campo político e o campo da arte em que se insere). A teoria de Chantal Mouffe de democracia radical e práticas artísticas agonísticas será utilizada aqui para compor esta noção de agenciamento artístico.
\end{abstract}

PALAVRAS-CHAVE: arte e esfera pública, agenciamentos artísticos, arte e política, arte no espaço urbano

ABSTRACT: This article intends to investigate, through the work Arte Cemiterial by the artist Paul Bruscky, the relationship between art and public sphere. In this way, I start from the sociological concept of artistic agency to analyze how work acts both in the urban space where it was carried out and in the public sphere in which it participates (the political field and the field of art in which it is inserted). Chantal Mouffe's theory of radical democracy and artistic agonistic practices will be used here to compose this notion of artistic agency.

KEYWORDS: Art and the Public Sphere, artistic agency, art and politics, art in the urban space

\footnotetext{
*Raíza Ribeiro Cavalcanti é Doutora em Sociologia pela Universidade Federal de Pernambuco. Também é graduada em Ciências Sociais (Universidade Federal de Pernambuco) e Comunicação Social - Jornalismo (Universidade Católica de Pernambuco). Atualmente desenvolve propostas de projetos independentes na área das artes visuais e atualiza constantemente o blog Reflejo (https://blogreflejo. wordpress.com// com ensaios e textos críticos. E-mail: raizacavalcanti@gmail.com.
} 
Em artigo intitulado Como se existisse a humanidade, a pesquisadora Marisa Flórido reflete sobre o comum e como a arte pode ainda representá-lo ou elaborá-lo sem cair em essencialismos. Isso porque, para a autora, o contexto epistemológico atual impele a pensar na dissolução do sujeito, entre outras formas de questionamento da ideia de totalidade bastante cara à modernidade ocidental. Em suas palavras:

São as figuras de totalidade, unidade e universalidade sonhadas pelo ocidente e prometidas pela modernidade que se dissolvem: as categorias artísticas como unidades distintas, bem delimitadas e autônomas entre si e em relação com o mundo; o sujeito como unidade substancial e originária; a esfera pública iluminista e seus cidadãos fraternos; a comunidade universal do gosto e seus espectadores idealizados. Como a arte responderia a essas dissoluções? (CESAR, 2007, p. 18)

Essa pergunta feita por Flórido é o cerne do que pretendo observar neste artigo, através da análise de como as práticas artísticas atuam não apenas na esfera pública em que se realizam, mas no contexto mais amplo do campo da arte onde estão inseridas. A arte que elabora as dissoluções epistemológicas essencialistas, a exemplo da desconstrução da noção de sujeito, é também a arte que atua em uma esfera pública não mais idealizada em torno do consenso, mas permeada constantemente pelo conflito e pela abertura dos sentidos. E esta arte, neste artigo, está representada pelo trabalho Arte Cemiterial, do artista pernambucano Paulo Bruscky.

A partir do conceito de agenciamento artístico ${ }^{1}$, gostaria de propor uma análise sociológica da ação Arte Cemiterial, observando como este trabalho atua no interior de uma esfera pública ampliada, provocando ruídos no interior da mesma até os dias atuais. Por esfera pública ampliada entendo o espaço público não apenas como o lugar urbano onde a obra se realiza, mas envolvendo também a esfera do discurso político e do campo da arte. Desse modo, pretendo analisar a agência de Arte Cemiterial a partir da perspectiva de que este é um trabalho que acontece no espaço urbano da cidade do Recife, mas mobiliza sentidos políticos e estéticos que se referem tanto à esfera política mais ampla quanto ao campo da arte em que também se insere. 


\section{Arte e esfera pública agonística: Chantal Mouffe, a ideia de prática artística e os agenciamentos artísticos}

Para iniciar a proposta de análise da ação realizada por Arte Cemiterial no interior da esfera pública em que se insere, é preciso esclarecer aqui o quê estamos entendendo por este termo. Neste ponto, é necessário falar um pouco sobre a teoria da autora Chantal Mouffe (2007) sobre a prática artística e sua relação com o que ela chama esfera pública agonística.

Para Mouffe, as práticas artísticas críticas são as que impugnam o consenso dominante e realizam, assim, uma luta discursiva no social, questionando hegemonias e identidades estabilizadas, atuando preferencialmente no seio da esfera pública. A arte, em confronto direto com o espaço público e a esfera pública, torna-se potencializadora de práticas que incidem na construção social desses espaços, jogando com os discursos dominantes.

Essa definição de Mouffe do que são as práticas artísticas críticas, no contexto da arte contemporânea, se conecta a uma ideia de democracia radical, em que o espaço público é considerado agonista, ou seja, como permeado pelo conflito e onde o consenso torna-se uma impossibilidade, e no qual as lutas discursivas podem fazer emergir novas identidades políticas, anteriormente soterradas pela hegemonia dominante. Em sua proposta agonística do espaço público, "a arte crítica é a que fomenta o dissenso, a que torna visível o que o consenso dominante costuma obscurecer e apagar. Está constituída por uma diversidade de práticas artísticas encaminhadas a dar voz a todos os silenciados no marco da hegemonia existente". (MOUFFE, 2007, p. 67) Essa atuação crítica, para se realizar, necessita que os atores concebam o espaço público como agonisticamente constituído. Do contrário, as ações artísticas, em relação a seu público, se tornam a de formação de consensos, mesmo que estes tentem ser críticos. Isso porque na democracia radical defendida por Mouffe, o objetivo não é a busca de consensos, mas o constante enfrentamento do conflito inerente à esfera pública.

Tendo a ideia de Mouffe em mente, pensei o conceito de agenciamento artístico. Com esse conceito quero me referir às ações que os trabalhos artísticos realizam no interior do campo da arte e da esfera pública onde estão inseridos. Analisar os trabalhos a partir dessa noção é vê-los como protagonistas de uma ação discursiva e crítica que não se restringe ao discurso autoral, curatorial e museal que os definem e podem vir a restringi-los. Se é verdade que os discursos dos autores e das instituições onde os trabalhos circulam irão conformá-los e 
delimitá-los, também é verdade que o discurso que o trabalho estrutura e põe em evidência também segue entrando em conflito nessas trocas, inserindo outros sentidos no interior das instituições onde estão situados.

Porém, antes de pensar a arte como agência no interior de uma esfera pública agonista, é importante observar melhor a relação entre arte e espaço público. Desse modo, tem-se que desde o Renascimento, a presença da arte na cidade se relacionava com os monumentos e as afirmações nacionais, religiosas e políticas no espaço público. O monumento é, até hoje, um importante meio de ocupação política do espaço, marcando-o simbólica e historicamente e enfatizando determinada narrativa dominante ${ }^{2}$. O monumento, desse modo, estabelece uma relação direta e permanente com o lugar onde está situado, na medida em que o significa política e historicamente.

Com a emergência da arte moderna, a escultura foi desconectada dessa relação direta com o espaço, tornando-se móvel. Por outro lado, os desenvolvimentos urbanos posteriores passaram a levantar distintas questões em relação ao espaço público: novos modos de transitar, de ocupar e habitar emergiram. E as vanguardas artísticas, em sua crítica à arte autônoma e à sociedade burguesa, ao proporem a reconexão da arte com a vida, entendem que isso deve ser feito através da ocupação do espaço da cidade. As deambulações, proposições de mergulho afetivo na cidade, através da construção de mapas afetivos das ruas e das longas caminhadas sem destino, surrealistas e dadaístas, foram ações que os situacionistas, a partir da década de 1950, retomaram. A crítica ao automatismo do espaço urbano, sua ordenação, que tirava deste a dimensão da convivência e do simples deixar-se estar, depois se converte em crítica ao uso capitalista da cidade.

A partir dos anos 1960, as ações neovanguardistas (a exemplo do grupo Fluxus, minimalismo, arte conceitual, entre outras) irão articular as ideias de ação no espaço público, site-specific, arte ambiental, happening, inserindo esses conceitos no interior do que é compreendido e aceito como arte no campo. A questão da arte urbana (ou intervenção) emerge no campo como uma prática reconhecida e aceita, podendo transitar entre o espaço da cidade e o espaço institucional da arte. 
Essa nova condição, considerada por muitos como de neutralização da crítica, é a que é problematizada por Mouffe quando a autora apresenta que a prática artística, em sua ação política de organizar o social, pode ser conformadora do mesmo ou sua crítica. O fato de estar aceita no campo como prática artística não é a única condição que determina se uma ação está totalmente neutralizada. Sua relação com o espaço ou com a esfera pública, seu agenciamento no interior do mesmo, ou seja, a articulação de discursos que realiza, são melhores indicadores de se uma prática artística é política, ou seja, se é participante da conformação e da estruturação de uma dada configuração social ou se contém o político e, assim, insere o dissenso e a contestação no social.

Essa dupla condição da arte é definda por Rosalind Deutsch (1996), em ensaio no qual são analisadas ações de arte pública nos anos 1980 em Nova York, em que a autora compara intervenções definidas como "nova arte pública" e ações de artistas como Krzysztof Wodiczko, Hans Haacke e Louise Lawler. Baseada em autores como Henri Lefebvre, a autora investiga as relações capitalistas com o espaço urbano geradoras de revitalizações urbanas que promovem gentrificação, especulação imobiliária e o uso da arte nesse processo. Analisando projetos que se realizaram nos anos 1980, a autora investiga as relações da arte com a conformação de espaços economicamente especulados, pondo-as em relação a outras que revelam essa constituição social, econômica e política do urbano.

Essa "nova arte pública", emergida na década de 1980, estaria relacionada, segundo Deutsche, a uma retórica funcionalista e a uma política conservadora em relação à cultura, a qual emergiu com bastante força nessa década de expansão do discurso neoliberalista. Ainda segundo a autora, "em contraste com uma concepção anterior de arte pública como 'arte no espaço público', a nova arte pública foi apregoada como 'socialmente responsável', site-specific e funcional porque auxiliava o desenho urbano e então contribuía para a beleza e utilidade destes novos espaços urbanos revitalizados." (DEUTSCHE, 1996, p. 15) Ou seja, seguindo um caminho similar a várias outras tendências artísticas capitalizadas pelo discurso neoconservador e economicista desse período, essa nova arte urbana aparecia como um meio de promover a valorização do espaço urbano controlada por grupos e forças conservadoras.

O contraponto a essa tendência, diz Deutsche, era a ação de artistas como Haacke e Louise Lawler. Segundo a autora, 
diferente da pintura da cidade expressionista, eles não pretendem transcender as condições sociais e urbanas. Ao contrário, eles chamam a atenção para essas condições. [...] eles empregam táticas espaciais desenvolvidas pela arte pós-moderna - especificidade do lugar, crítica institucional, críticas da representação -para revelar as relações sociais que constituem tanto a estética como o espaço urbano. (DEUTSCHE, 1996, p. 16)

Essa ação de crítica desveladora, que se inseria no interior do espaço público e institucional para se realizar, típica da tendência que ficou conhecida como Crítica Institucional, aparece aqui citada como uma prática de relação entre arte e espaço público em que a dimensão ruptora - ou do político, como diria Mouffe - emerge. Não se trata mais de colaborar para conformar um espaço a serviço do uso capitalista e da especulação financeira, mas de desnaturalizar essa maneira de pensar e viver o espaço público, de inserir o que esse tipo de constituição deixa escondido.

Apesar de se basear em Lefebvre e não Mouffe, a reflexão de Deutsche se aproxima muito do que esta última define como prática artística agonística. Isso porque Deutsche irá definir o que seria uma arte pública genuinamente responsável como aquela capaz de desapropriar o espaço de sua dominação pelo capitalismo e pelo poder de Estado. Para ela, na tradição da arte site-specific radical, a arte pública deve romper, mais do que assegurar, a aparente coerência destes novos espaços urbanos. (DEUTSCHE, 1996)

Voltando-nos ao Brasil mais especificamente, temos que já na década de 1930 o artista Flávio de Carvalho propunha experiências urbanas nas quais questões como a conformação realizada pelos costumes e tradições nas reações dos indivíduos eram postas em evidência no seio do espaço público. Em Experiência n. 2, a qual o artista chamou de experiência de psicologia das multidões, Carvalho acompanhou uma procissão de Corpus Christi andando de costas para a imagem e usando um boné de veludo verde. Ameaçado de linchamento pela multidão que acompanhava o cortejo, teve que correr e esconder-se em uma lanchonete até ser escoltado pela polícia para uma delegacia. Já em 1956, em Experiência n. 3, Carvalho propôs um novo traje para o homem contemporâneo dos trópicos, que seria composto por uma camiseta, saia, meia arrastão e sandálias de couro. O artista, então, caminhou pelas ruas do centro de São Paulo usando o seu traje a fim de detectar a reação do público à sua nova proposta.

Estas ações de Carvalho são consideradas como uma das primeiras intervenções urbanas brasileiras, conectando o país às ações vanguardistas europeias, surrealistas e dadaístas, de 
intervenção na cidade. Mas, segundo pondera o crítico Fernando Cocchiarale (2004), não é tão simples afirmar um pioneirismo deste artista em uma produção contemporânea nacional, visto que, segundo o autor, o próprio artista não considerava suas experiências como artísticas, nem as tomava como centro da sua produção, que continuou sendo a pintura. Tampouco essas experiências realizaram impactos diretos na produção de outros artistas da época, nem imediatamente posteriores, sendo retomada como influência artística apenas nos anos 1990. Segundo o autor: "Essas duas intervenções só começaram a ser incorporadas à gênese de nossa arte mais radical pelo discurso crítico dos anos 1990. Sua influência, portanto, é fenômeno retrospectivo, recentemente construído". (COCCHIARALE, 2004, p. 68)

Posteriormente, já na década de 1960, a expansão das ações neoconcretistas para o ambiente, a reivindicação da participação do outro e de um espaço de crítica, tanto da instituição arte quanto do contexto histórico, social e político do Brasil, levaram à emergência de uma neovanguarda brasileira que abre caminho para a arte contemporânea do país. É o período da Nova Objetividade e da Nova Figuração, movimentos artísticos que abriram o cenário da arte brasileira para os objetos, os happenings, as instalações e a arte participativa. Nesse momento, os parangolés de Oiticica surgem reivindicando a presença do outro marginal como centro da obra, autor e espectador privilegiado, evidenciando essa identidade pobre e favelada em uma esfera pública que o invisibilizava.

Em finais da década de 1960, emerge no Rio de Janeiro uma geração que ficará conhecida pela forte combatividade política de suas ações, as quais, majoritariamente, aconteciam no espaço público ou estavam fortemente influenciados por ele. É a geração conhecida, após o crítico Fernando de Morais assim a nomear, como a da arte de guerrilha, pelas ações contundentes, mas ao mesmo tempo fugazes e efêmeras, que realizavam. É quando Artur Barrio realiza suas Situações, Cildo Meireles promove instalações e ações como Inserções em Circuitos Ideológicos e Antonio Manuel insere jornais falsos para circular em Clandestinas. A crítica política e a referência ao contexto ditatorial marca o discurso dessas obras, situando-as sempre nessa leitura de guerrilha, ou seja, na dimensão do embate político direto. Essa dimensão é inegável nessas obras, mas as leituras que enfatizam esse aspecto acabaram por torná-las reféns de um sentido político que as categoriza em termos históricos da arte, incidindo em sua leitura posterior pelo campo da arte. Porém esses agenciamentos, para além da retórica política que os acompanha, incidiram em estruturas no interior do campo social e da arte, provocando ruídos não apenas no contexto político direto, mas também estéticos, artísticos e institucionais. 
Um adendo a esse ponto é a consideração de que essa narrativa histórica desconsidera, ou não dá a devida ênfase, aos processos realizados em outros polos de produção artística nacional, a exemplo do que acontecia na cidade do Recife. No período dos anos 1960, artistas como Paulo Bruscky, Daniel Santiago, Ypiranga Filho, Unhandeijara Lisboa, Sílvio Hansen, Jomard Muniz de Brito, entre outros, realizavam ações baseadas tanto no movimento tropicalista emergente no país (do qual Jomard foi um ativo participante, tendo escrito seu manifesto), na poesia visual, na intervenção urbana e na criação multimeios (na qual Bruscky é o mais destacado). Estando conectados em rede através da arte postal, formaram núcleos de diálogo e de produção conjunta com outras partes do nordeste, incluindo João Pessoa e Natal. O uso da palavra, da ironia e do conceito era uma marca forte dessas ações. Uma das mais conhecidas é a ação de Paulo Bruscky chamada Arte Cemiterial, a qual será analisada a partir de agora.

\section{Arte Cemiterial: Paulo Bruscky e a cidade como suporte de produção}

Como mencionamos acima, a historiografia da arte brasileira quase sempre se refere ao processo iniciado pela semana de 1922, passando pela emergência do concretismo, sua ampliação ao neoconcretismo e culminando na Nova Objetividade e na Nova Figuração como

processos formadores da arte contemporânea nacional. Essa maneira de narrar a formação do campo da arte contemporânea brasileiro obscurece o que aconteceu em outras capitais do país, como no caso do Recife.

No contexto brasileiro, Recife possuiu, por vários momentos, destaque por sua produção cultural. No início do século XX, nomes como os dos pintores Vicente do Rêgo Monteiro e Cícero Dias, ambos recifenses, foram reconhecidos internacional e nacionalmente por suas produções. A obra de Cícero Dias é classificada por críticos e historiadores como oscilando entre um pré-cubismo (como afirma Ronaldo Brito) ou sendo uma experimentação que se utiliza de algumas referências cubistas pra construir uma imagem pictórica própria, quase nonsense, em que a cultura do açúcar e suas contradições eram bastante evocadas. A referência constante ao contexto de Pernambuco em suas obras marca uma tendência seguida por outros artistas, como Lula Cardoso Ayres e, posteriormente, Abelardo da Hora.

Vicente do Rêgo Monteiro, por sua vez, tem tido sua obra bastante revisitada e pesquisada por conter traços estéticos bastante presentes em ações posteriores na história da arte 
moderna brasileira. Pintor, artista gráfico, pesquisador e poeta, a obra do artista atinge uma amplitude de meios e, desde antes de 1922, realizou pesquisas sobre as questões indígenas nacionais (utilizou bastante a referência à cerâmica marajoara), relacionando elementos que irão compor o manifesto antropofágico, escrito posteriormente por Oswald de Andrade. Sua produção precoce em poesia visual, experimentações sonoras, além da ilustração e da arte gráfica, também foram uma importante referência, ainda que não suficientemente reconhecida, visto que uma geração posterior irá retomar essa prática e expandi-la (Paulo Bruscky, por exemplo, investigou a obra do artista e possui um grande acervo de documentos, arquivos e obras de Vicente do Rêgo Monteiro).

Caligrama

(Fonte: Vicente do Rego Monteiro - Poeta, Tipógrafo, Pintor. Org.: Paulo Bruscky, 1956.)

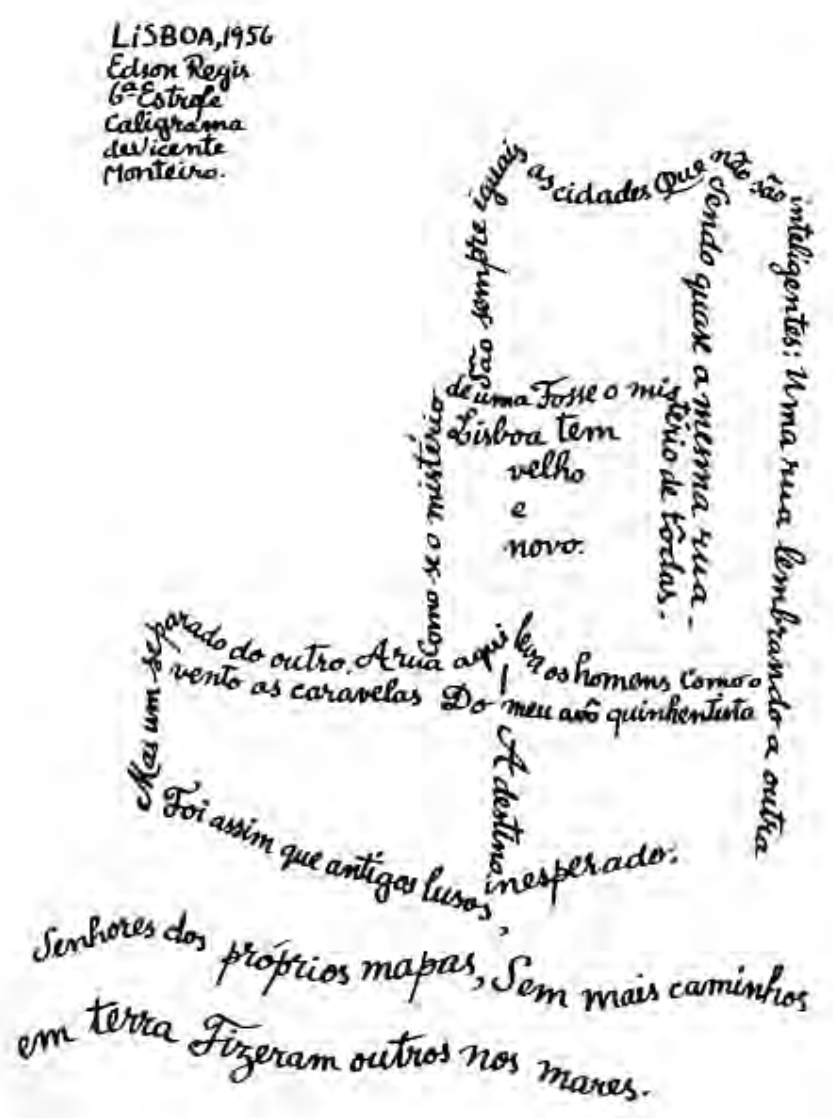


A produção modernista regionalista, por sinal, foi bastante potente no Recife, que se tornou um dos principais polos dessa produção, graças à atuação de Abelardo da Hora como agente articulador. Esse artista, ao ganhar reconhecimento nacional após exibir no Rio de Janeiro, então capital nacional, voltou ao Recife com o intuito de ampliar a produção modernista regional, que ele priorizava em detrimento das tendências mais formalistas. Nesse processo, articulou exposições e a reunião de artistas em tornos de grupos como a Sociedade de Arte Moderna do Recife, em 1948, e o Atelier Coletivo, em 1952. Esses dois grupos tinham como objetivo formar e fomentar a produção artística engajada, reunindo em torno de si importantes artistas do período e chegando a tornar-se a tendência hegemônica da arte na cidade, influenciando bastante o imaginário artístico local.

O cenário recifense ficou tão impregnado com a questão social na arte que, segundo depoimento do artista José Cláudio (ex-integrante do Atelier Coletivo), mesmo aqueles que eram mais simpáticos à tendência reflexiva do modernismo (mais voltada ao abstracionismo) não ousavam pintar outro assunto que não fossem as figuras do povo, trabalhadores, camponeses, feirantes, vaqueiros, crianças pobres, entre outros (AMARAL, 1984). Essa preocupação, presente desde Cícero Dias e os primeiros modernismos pernambucanos, é apropriada por Abelardo da Hora e outros artistas a partir de finais da década de 1940 e início da de 1950 com um ponto de vista do questionamento social e o desejo de educação das massas através da arte. Em 1962, o governo de Miguel Arraes reuniu artistas e intelectuais da cidade para criar os Movimentos de Cultura Popular, mais conhecidos como MCPs.

Os MCPs marcaram a história do engajamento social através da cultura, inspirando a criação de outros centros parecidos pelo Brasil, que ficaram conhecidos como Centros de Cultura Popular (CPC). Nestes centros, intelectuais como Paulo Freire e artistas como Abelardo da Hora, realizavam ações como oficinas, cursos, exposições, apresentações teatrais, edições de livros e cartilhas com o fim de educar para a emancipação e politizar as massas para a luta social. A função pedagógica da arte aqui era destacada, colocando-a a serviço da mobilização.

Porém, em 1964, com a emergência da ditadura, os MCPs foram desarticulados e muitos dos seus criadores e participantes foram exilados pelo regime. O regime se recrudescia e a produção artística, por outro lado, se diversificava, incluindo elementos experimentais conectados com discursos artísticos emergentes no campo da arte mundial, a exemplo do conceitualismo. 
Desse modo, a partir dos anos 1970, a cidade de Recife ficou dividida entre uma produção modernista de cunho regionalista, associada aos movimentos populares de esquerda na cultura, e o diálogo com uma produção conceitual que tomava forma nas ações performáticas e de poesia visual de um grupo de artistas. Daniel Santiago, Paulo Bruscky, Ypiranga Filho, Jomard Muniz de Brito e Sílvio Hansen foram artistas que realizaram, na cidade, um importante movimento de poesia visual. Também realizavam performances, vídeos, intervenções poéticas nos jornais e na cidade e produziam trabalhos em suportes os mais variados, a exemplo das ações de xeroarte e xeroperformances (usando máquina xerox), fax arte (transmissão em tempo real através do uso do fax), experimentações com som e com máquinas como a de radiografia e de eletroencefalograma de Paulo Bruscky. Este último, aliás, foi um dos primeiros (e talvez único) brasileiros a fazer parte da rede artística mundial Fluxus, impulsionando a produção de arte-correio da cidade (hoje mundialmente conhecida).

Esse preâmbulo bastante resumido e limitado é necessário para situar a produção de Paulo Bruscky dentro de um contexto de efervescência e movimentação cultural mais particular. Ao passo que o campo da arte do Recife, em sua constituição, obviamente dialogou (e ainda dialoga) com o que se produzia no resto do país e também do mundo, possuía, por outro lado, algumas dinâmicas próprias que necessitam ser elucidadas para uma compreensão mais precisa. Contextos de ação e de influências diversas marcam a produção da geração da qual emerge Bruscky: desde a multiplicidade da produção de Vicente do Rêgo Monteiro, passando pela força das artes gráficas, evidenciada nos anos 1950 pela editora O Gráfico Amador, comandada na época por Aluísio Magalhães e Gastão de Holanda. Tudo isso junto a uma crítica que ia desde o contexto político geral de ditadura, passando pela crítica corrosiva a uma ideia de pernambucanidade forjada por intelectuais, políticos e artistas defensores do regionalismo, chegando a uma consciência política da desigualdade e da injustiça social.

Considerar esse contexto, ao iniciar a análise de ações de Bruscky, tem a função de desenhar os contornos de um campo da arte onde o artista opera, através da sua interrelação com o campo social mais amplo. Esse contexto informa de maneira bastante evidente o discurso do artista sobre sua obra e também sua autorrepresentação, além dos discursos criados pelos curadores para definir e classificar sua produção. 
Uma das maneiras encontradas em textos curatoriais e no texto do próprio artista para classificar sua produção é a ideia de multiplicidade. O uso de distintas mídias, a fluidez da ação, a palavra como presença constante são algumas das características evidenciadas por estudiosos da obra deste artista e também por ele mesmo. Na análise dos textos sobre sua produção, é interessante notar a presença forte do autodiscurso de Bruscky, indicando que o artista, ele mesmo, ao elaborar conceitos sobre o que faz, informa outros textos no seio da cadeia intertextual da arte contemporânea.

Um dos elementos fortes presentes nos discursos do artista e sobre ele é a questão da intervenção urbana. A relação com a cidade do Recife, lugar onde nasceu e vive, é um elemento bastante evocado em suas falas. No trecho de uma entrevista concedida a Marília Andrés Ribeiro (2011), o artista afirma: "Recife sempre foi tradicionalista, açucareira, de famílias tradicionais. Mas é Recife e eu amo a minha cidade! É uma cidade que geograficamente, inclusive, pode ser trabalhada como suporte; ela tem uma geografia fantástica para intervenções urbanas como os rios, as pontes, as praias, os arrecifes. A geografia de Recife sempre me impressionou". (RIBEIRO, 2011, p. 17) Nesse trecho da fala de Bruscky, é possível identificar elementos relacionados ao contexto artístico-social da época em que iniciava sua atividade artística, a exemplo do posicionamento crítico em relação a uma identidade regional relacionada à cultura do açúcar e dos engenhos, criada e reafirmada tanto pelos modernismos locais quanto por escritos de intelectuais como Gilberto Freyre. O termo tradicionalista, depois reiterado em tradicionais, aparece, junto com açucareira, relacionando as noções de tradição e de açúcar que participam do discurso identitário definidor do que é ser nordestino e pernambucano. Ao iniciar o seguinte turno com "mas", evidencia o não envolvimento pessoal com o que afirma tradicional, colocando sua identificação em "eu amo a minha cidade" após esse outro termo.

Outro aspecto importante é que esse amor, seu sentimento positivo em relação ao lugar geográfico onde está situado, se relaciona a uma vontade de ação sobre o objeto do amor. O termo suporte, que no interior do discurso artístico contemporâneo significa o meio ou a mídia pela qual um trabalho é realizado, é aqui referido para falar da cidade. A cidade como suporte da intervenção urbana, descrita a partir das possibilidades de ação que promove, seja nos rios, nas pontes, nas praias ou nos arrecifes. 
Dentro desse trecho, temos já uma parte importante de como o artista representa sua relação da arte com o espaço público e como esta representação está permeada por sentidos simbólicos e históricos mais amplos, que se referem ao nível social. A cidade foi usada várias vezes pelo artista em ações solo ou em dupla com Daniel Santiago, em experimentos expositivos e happenings os mais variados.

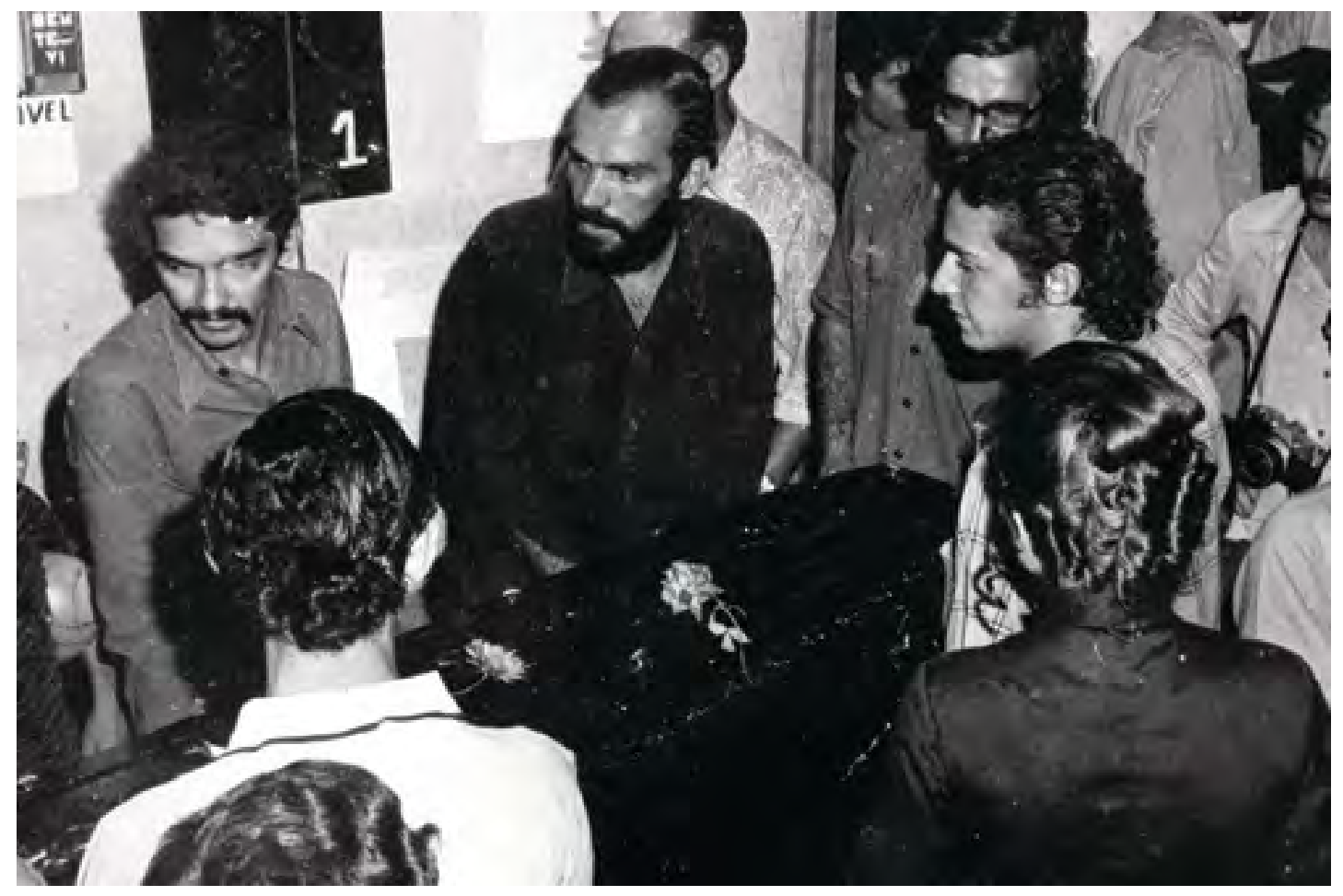

Arte Cemiterial

(Foto: Acervo Paulo Bruscky, 1971) 
Uma destas ações foi a realização da mostra de Arte Cemiterial, realizada na Empresa de Turismo de Pernambuco (Empetur), em 1971. A ação consistia da realização de uma exposição, organizada por Bruscky, na qual vários artistas e poetas foram convidados a criar ações e objetos. Todos os elementos na mostra se relacionavam ao absurdo ou à morte e o próprio artista chegou dentro de um carro funerário carregando um caixão ao evento. Em depoimento à pesquisadora, o artista relembra a ação:

Foi fechado na noite da abertura pelo exército. Eu fui censurado, né? Foram fechados... no dia seguinte... eu nunca tive medo, um dia eu vou ter que morrer, a antecipação por uma causa justa... não tinha medo, eu nunca tive medo da morte também... quem enfrentou a ditadura... quem enfrentou o exército não tem medo de nada... e no outro dia eu convoquei os amigos, fiz um caixão pequeno, saí defronte da galeria fechada... no dia seguinte e fiz um enterro naquela época na rua da Aurora, ali na ponte Princesa Isabel, você entrava assim e até a margem do rio tinha uma areia... eu fiz um enterro... um enterro simbólico da censura, da ditadura... com poucos amigos, porque você só sabe os amigos que você tem... no período da ditadura foi quando eu vi os amigos que eu tinha. [...] Ela aconteceu na Empetur, na Empresa de Turismo de Pernambuco e foi fechada na noite de abertura. Tinha de tudo, não era só o caixão. Tinha uma cama... eu tenho esse filme. Um deles, o outro eu perdi na cheia, esse eu recuperei... onde as pessoas se deitavam, entendeu? Tinha um trabalho que começava na rua, umas setas, tinha uma escada, tinha umas pernas de cera, de ex-votos, tinha um trabalho com uma luz vermelha com colagens sobre o movimento estudantil que eu fiz parte e tinha um trabalho de Tarcísio Pereira que era no centro dessa caixa que eles destruíram que é a grande marcha... (Depoimento de Paulo Bruscky à pesquisadora em 12 de março de 2015)

Este trecho da memória do artista, carregado de referências à morte e ao exército, amplia o símbolo "morte" existente no texto-arte de Arte Cemiterial. Isso porque, em suas memórias, o artista reforça o contexto social de ditadura militar da época, recrudescido após a instituição do Ato Institucional no 5, o qual fechou o Congresso e ampliou a violência policial sobre a população civil. Na parte "Foi fechado na noite da abertura pelo exército. Eu fui censurado, né? Foram fechados... no dia seguinte... eu nunca tive medo, um dia eu vou ter que morrer, a antecipação por uma causa justa... não tinha medo, eu nunca tive medo da morte também... quem enfrentou a ditadura... quem enfrentou o exército não tem medo de nada", o destaque está nas afirmações categóricas que faz de sua subjetividade combativa, do não ter medo. 0 termo "enfrentar", conjugado em primeira pessoa do passado, afirma a dimensão de combate 
afirmada pelo artista em sua autorrepresentação. Considerando isso, a construção identitária que realiza o artista é importante e revela seu posicionamento político de enfrentamento, o qual compõe o discurso que participa da constituição de Arte Cemiterial. Esse ethos subversivo é aqui assumido de maneira evidente e serve para dar sentido aos trabalhos e também às ações.

Pensada inicialmente como exposição, Arte Cemiterial acabou tornando-se em um happening, uma ação entre protesto e intervenção urbana, quando o artista simula um enterro. Ao relatar o fechamento da mostra pelo exército, o artista formula como a ação foi transformada: “[...] e no outro dia eu convoquei os amigos, fiz um caixão pequeno, saí defronte da galeria fechada... no dia seguinte e fiz um enterro naquela época na rua da Aurora, ali na ponte Princesa Isabel, você entrava assim e até a margem do rio tinha uma areia... eu fiz um enterro... um enterro simbólico da censura, da ditadura.... Aqui, novamente, o termo ditadura reaparece, dando sentido ao texto arte de Arte Cemiterial. A ação foi ampliada e, de uma mostra inusitada no interior de uma estrutura institucional, a Empetur, passou para uma intervenção urbana contestatória.

O agenciamento realizado por essa obra parece ficar claro após a reação do exército e sua preocupação em fechar a mostra. Se fosse só exposição, haveria promovido uma provocação no interior das estruturas dominadas pela ditadura militar da época. Mas ao tornar-se performan$c e$, esse agenciamento expande seu alcance para o espaço urbano, evidenciando ainda mais o ruído causado por ele na esfera pública. Enquanto exposição, já era uma espécie de afronta. Invadia uma instituição municipal com obras absurdas e irônicas, provocando o espectador (e, às vezes, até enfurecendo-o). Instituição esta que era voltada para o patrocínio do turismo da cidade, ou seja, de sua imagem - que, se supõe, deveria ser uma boa imagem a fim de atrair visitantes. Essa instituição é tomada pela ironia e pela iconoclastia, não só dos trabalhos da mostra, mas de sua própria organização, a exemplo do coquetel servido na abertura, chamado de "batida de sangue de vampiro." Também havia uma mesa em que capim era servido em pires aos visitantes, ao lado de um cartaz que dizia "sirvam-se".

O tom provocativo e irônico da mostra chamou a atenção do suplemento cultural do Diário de Pernambuco. Comentando o inusitado coquetel servido na abertura da mostra, o autor (que é desconhecido) escreve: "Numa mesa, uns pires cheios de capim. E um cartaz que dizia o seguinte: 'sirvam-se'. Um dos presentes escreveu no cartaz: 'Todos nós já jantamos. Mas 
sobrou o suficiente pra você, meu caro pintor'". (Diário de Pernambuco, Suplemento Cultural, 17 de outubro de 1971) O destaque dado no trecho à resposta do suposto visitante revela o posicionamento do jornal em relação ao trabalho. A representação direta do discurso de um suposto visitante, o qual não é identificado pelo jornal, revela uma evidente apropriação dessa fala para afirmar sua posição ideológica, claramente contrária ao artista e à ação. A tentativa de reverter a ironia do trabalho, imputando uma noção de considerar todos os visitantes como supostos estúpidos para o próprio artista, revela um posicionamento ideológico conservador do jornal, reativo à ação.

Essa reação contrária fica ainda mais evidente quando, no parágrafo final, ao relatar o que deveria ser o fechamento da mostra pelo exército, o autor do texto acaba por revelar sua opinião de maneira mais direta. No trecho:

O caixão de defunto que estava lá, num canto, sendo muito admirado pelos olhares curiosos, foi retirado. E os que vieram só pra olhar, também foram saindo de mansinho. Ficou só o desenhista-pintor. Já fora do local da exposição, ele comentava agitado: retiro a mostra segunda-feira. O que foi feito, para a felicidade de todos que desejam pensar mais na vida que na morte. (Suplemento Cultural do Diário de Pernambuco, 17 de outubro de 1971)

Nesse trecho, outro agenciamento importante de Arte Cemiterial se dá através da provocação ao jornal que acaba revelando seu posicionamento ideológico e político, além de conservador, favorável ao regime militar da época. Isso se torna evidente não a partir do que revela esse trecho, mas principalmente do que ele esconde. A cena relatada de pessoas saindo "de mansinho", ou seja, discretamente, a fim de não serem notadas, além da notícia de retirada do caixão, não revela o fato de que o exército foi ao local fechar a mostra. Ao afirmar que o caixão "foi retirado" usando a voz passiva, o trecho omite o autor da ação e, consequentemente, não revela o ato de censura realizado pela polícia do exército. Outro fato interessante é a representação direta, sem usar aspas, da afirmação do artista sobre a retirada da mostra na segunda-feira. E, na frase seguinte, essa fala é confirmada e comemorada pelo autor do texto como um alívio: "o que foi feito, para a felicidade de todos que desejam pensar mais na vida que na morte." Esse trecho evidencia bastante um alinhamento ao pensamento conservador da época. Além disso, a tentativa do jornal de universalizar sua opinião individual, "ao afirmar para a felicidade de todos que desejam" também é ideológica no sentido de promover uma suposta união de pensamento em torno do que é considerado correto e aceitável. 
Dentro desse contexto, ao seguir para a rua e realizar um cortejo de enterro da exposição que acabou na Ponte Princesa Isabel, na rua da Aurora (na área central da cidade do Recife), Arte Cemiterial continua provocando e desestabilizando a conformatividade que se tentava inserir no seio do social recifense da época. Além da ilegalidade da ação (eram proibidos ajuntamentos em locais públicos pela ditadura), o artista ainda provocava os sentidos de permitido e de proibido ao enterrar um caixão vazio na lama do rio. O que pode e o que não pode no espaço público? Quem está determinando essas leis e interdições? Se o simples fato de andar em grupo e enterrar algo em uma área pública se tornava ilegal, realizar essa ação e testar os limites da proibição era um desafio à arbitrariedade da lei que, também, era a contestação da legalidade da ação de repressão.

Além disso, o tom irônico revelado no texto do convite para o enterro da exposição revela novamente o posicionamento subversivo assumido pelo artista (e presente na representação do seu ethos). Reproduzindo os populares santinhos, memoriais feitos pelas famílias das pessoas falecidas, geralmente utilizando uma imagem de Jesus Cristo, o texto do convite para o enterro dizia: "A família Bruscky convida para o enterro da exposição do seu querido filho, primo, irmão, neto e amigo, Paulo Bruscky, a realizar-se no dia 16/10/1971. O féretro sairá da Galeria da Empetur, Avenida Conde da Boa Vista, 765, em direção ao aterro da rua da Aurora, onde será sepultado às 10h". (Texto do convite da performance de Arte Cemiterial, 1971).

O interessante desse convite é a ironia com convenções sociais relativas à morte, reproduzindo fielmente um santinho, além do jogo irônico dos termos. Importante destacar que o santinho anunciava a morte da exposição e não a do artista. Mas a confusão provocada pelo modo como o texto é constituído acaba sem deixar claro a quem se está enterrando. A ironia do convite, que reproduz o estilo de texto usado na produção desses santinhos, atinge sua eficácia ideológica quando provoca essa confusão no leitor.

Além disso, essa estratégia de reproduzir um estilo de texto tradicional insere a crítica à censura da mostra na esfera da linguagem tradicional e popular, na dimensão social mais ampla. Usar termos tradicionais também é uma referência de crítica ao tradicionalismo recifense da época, veementemente combatido por Bruscky e demais artistas de sua geração. Aqui, nos termos de Mouffe, o artista articula discursos na produção de uma luta discursiva que insere o ruído na hegemonia social. Usar o próprio texto hegemônico para subvertê-lo é uma ação de luta discursiva que insere sentidos deixados de fora pela hegemonia dominante. 
Mas o agenciamento mais interessante que Arte Cemiterial segue realizando é o de uma dimensão inescapável de sentido que opera, revelado através das distintas narrativas, às vezes contraditórias, que são feitas sobre ele. Nos textos de pesquisadores e curadores que escreveram sobre esta ação, a relação entre a mostra e a performance aparece relatada de formas diferentes da que relata o próprio artista. Em alguns, a situação da performance e da exposição são indiferenciados, revelando a tentativa de realizar uma compreensão de Arte Cemiterial posterior, tornando-a historicamente classificável. No relato da autora Cristina Freire (2006), por exemplo:

É certo que a rua se destaca nos projetos de Bruscky, em todas as suas dimensões e funções pelas ruas de Recife: informativa, simbólica e lúdica. Essas funções misturam-se sobretudo na década de 1970, que se inicia com a exposição/performance Arte Cemiterial. Nesse projeto, o artista organiza seu próprio enterro, e o trajeto do féretro pelas ruas de Recife termina na Galeria da Empetur. A ideia do enterro remete simbolicamente ao luto em que vivia a população brasileira com a restrição de seus direitos civis numa sociedade ditatorial. Os convites, na forma dos populares santinhos de oração, provocavam o moralismo vigente. Não por acaso, a exposição foi fechada pela Polícia Federal, no mesmo dia de sua abertura, e o artista, levado a prestar esclarecimentos. (FREIRE, 2006, p. 93)

Esse texto, de estilo acadêmico, realiza um relato histórico da ação, situando-a no interior de um contexto social e histórico. Comparando esse trecho do depoimento do artista com recortes de jornal da época da realização do trabalho, percebe-se que há contradição em algumas das informações relatadas, a exemplo do trajeto seguido pelo cortejo. No relato do artista e no convite para a ação, a Galeria da Empetur é o ponto de partida, passando a ser ponto de chegada no texto de Cristina Freire. Além disso, a informação sobre o enterro, que no convite é a de enterro da exposição, é relatada como enterro do artista, o que revela a potência da ironia contida no santinho, provocadora de confusões no leitor. A autora também não deixa claro os momentos que compõem Arte Cemiterial: a exposição, sua censura e a posterior ação urbana de enterro. O relato não diferencia esses momentos, reordenando-o dentro de uma classificação histórica.

Em outro texto, dessa vez de estilo mais curatorial, de autoria da curadora Cristiana Tejo (2009), a ação aparece assim relatada: 
Em Arte Cemiterial (1971), temos novamente um duplo. O artista elabora uma performance do seu enterro. Todos os detalhes são levados em consideração: o convite-santinho utiliza o vocabulário e o formato dos convites de missa de sétimo-dia (o que levou a muitos a não lerem o que estava verdadeiramente escrito: "A família Bruscky convida para o enterro da exposição de seu querido filho"), o caixão e todos os rituais funerários são seguidos à risca. Bruscky vai na frente do cortejo, que ganha as ruas do Recife a caminho da galeria da Empetur. Quem está enterrado? Seria o cidadão, o artista ou o homem? O ato é uma clara alusão a um sentimento generalizado de luto vivido pela sociedade brasileira. A exposição acaba sendo fechada pela Polícia Federal e Paulo Bruscky acaba sendo levado para prestar depoimento. (TEJO, 2009, p. 31)

Nesse trecho pode-se observar, em primeiro lugar, novamente o conceito de cadeia intertextual criado por Norman Fairclough $(2001)^{3}$ operando, na medida em que os sentidos de textos anteriores são reatualizados em novos textos, criando cadeias discursivas, neste caso, sobre a interpretação de Arte Cemiterial (a qual acaba participando também da constituição do seu texto-arte).

Nesses dois textos, vemos que é inserido na obra um sentido de representação do luto que estaria sendo vivido pela sociedade sob o jugo da ditadura militar. Essa leitura participa da constituição tanto da obra como crítica à ditadura quanto do artista como subversivo, replicando o ethos representado pelo artista em sua autorrepresentação. A replicação dessa leitura em dois textos reforça esse sentido e passa a circulá-lo como oficial no interior do campo da arte, criando espaços de significação em seu interior.

Outro dado interessante é que Cristiana Tejo replica a informação de que o artista realiza a performance do seu enterro, apesar de chamar a atenção para o fato de que a ironia contida no convite pode provocar confusão em seu leitor. Também replica a informação de que o trajeto do cortejo se deu em direção à galeria, não saindo dela.

Esses dois exemplos citados, longe de tentarem desqualificar as autoras ou a narrativa construída em torno do trabalho, pretendem revelar a dimensão de sua inapreensibilidade. Sendo um trabalho possível de ser retomado apenas através do relato de seu autor e dos registros documentais que deixou, provoca a existência de distintos relatos e narrativas. Essas narrativas, ao encontrarem-se com as do artista e a dos documentos deixados por Arte Cemiterial, seguem em conflito, deixando uma incerteza da veracidade de todas as elas. Quem está 
certo? O artista? A pesquisadora? A curadora? Ninguém sabe. Aliás, a pergunta mais precisa que Arte Cemiterial provoca é a de se existe o verdadeiro (ou absoluto ou correto). Um agenciamento, que questiona legitimidades e essencialismos, continua questionando-os até hoje, nas silenciosas contestações que realiza das narrativas construídas sobre si. E que também vai realizar sobre essa outra narrativa aqui construída.

Desse modo, voltando à pergunta feita por Marisa Flórido a qual citamos no início deste texto, "Como a arte responderia a essas dissoluções?", temos que agenciamentos artísticos como o de Arte Cemiterial são uma das respostas possíveis. A agência de contestação de legitimidade que realiza no interior não só do espaço público, mas também da esfera social mais ampla e do campo da arte, é uma dessas formas de atuação crítica que contesta essencialismos e evidencia o que os discursos naturalizantes e hegemônicos da esfera pública não revelam. É uma ação que reivindica o comum através da participação crítica que insere o conflito em uma esfera pública dominada por um discurso hegemônico repressor. O enterro da exposição é também o nascimento de novos sujeitos-artista e espectadores. E a existência continuada no tempo de Arte Cemiterial é um dado sobre a imortalidade da arte, sempre renovada e ressuscitada a cada nova relação, discurso e apresentação que dela se faz.

Recebido em 07/03/2017 e aprovado em 05/05/2017.

\section{Notas}

10 conceito de agenciamento artístico foi criado por mim em minha tese de doutorado intitulada Agenciamentos Artísticos: uma análise sobre a ação dos trabalhos artísticos no interior do campo da arte brasileiro. A referida tese foi defendida no primeiro semestre de 2016.

2 Um exemplo é o Monumento aos Bandeirantes, situado em frente ao Parque Ibirapuera, São Paulo. Enfatizando a narrativa colonialista de dominação pelos bandeirantes, esse monumento tem sido questionado e alvo de ações críticas de manifestantes que discordam dessa narrativa.

3 O conceito a que me refiro neste trecho é a noção de Cadeia Intertextual criada por Norman Fariclough (2001) que, na análise de discurso, se refere à replicação de um discurso em outros, formando uma cadeia. Por exemplo, o discurso do trabalho artístico entra em uma cadeia de outros discursos quando gera discursos curatoriais. 


\section{Referências}

AMARAL, Aracy. Arte para quê? a preocupação social na arte brasileira 1930-1970. São Paulo: Nobel, 1984.

CESAR, Marisa Flórido. Como se existisse a humanidade. Arte e Ensaios, Revista do Programa de Pós-Graduação em Artes Visuais, EBA-UFRJ, Rio de Janeiro, n. 15, 2007, p. 17-25.

COCHIARALLE, Fernando. A (outra) arte contemporânea brasileira: intervenções urbanas micropolíticas. Arte e Ensaios, Revista do Programa de Pós-Graduação em Artes Visuais, EBA-UFRJ, Rio de Janeiro, n. 11, 2004, p. 66-71.

DEUSTCH, Rosalynd. Evictions: Art and Spatial Politics. Londres: The MIT Press, 1996.

DINIZ, Clarissa (org). Pernambuco Experimental. Rio de Janeiro [s.n], 2014, 250p. (catálogo de exposição, 10 de dezembro de 2013 a 30 de março de 2014, Museu de Arte do Rio de Janeiro).

FAIRCLOUGH, Norman. Discurso e mudança social. Brasília: UnB, 2001.

FREIRE, Cristina. Paulo Bruscky: Arte, arquivo e utopia. Recife: Companhia Editora de Pernambuco, 2006.

MOUFFE, Chantal. Prácticas artísticas y democracia agonística. Barcelona: Museu d’Art Contemporani de Barcelona, 2007.

RIBEIRO, Andrés Marília; SILVA, Fernando Pedro da. Paulo Bruscky. Belo Horizonte: Circuito Atelier, 2011.

TEJO, Cristiana. Paulo Bruscky: arte em todos os sentidos. Recife: Companhia Editora de Pernambuco, 2009. 